\title{
Psychiatric Aspects Of MDMA (3,4-Methylenedioxymethamphetamine): The 'Diathesis-Stress' Explanatory Model
}

\author{
A.C. Parrott ${ }^{*}$
}

Department of Psychology, University of Swansea, Swansea SA2 8PP, Wales, UK

Keywords: MDMA, ecstasy, diathesis, psychiatry, depression, stress, anxiety, schizophrenia.

\section{INTRODUCTION}

The empirical literature on psychiatric functioning in recreational Ecstasy/MDMA use will be reviewed, and the main explanatory models compared.

\section{METHODS}

3,4-methylenedioxymethamphetamine (MDMA) or 'Ecstasy', is a powerful sympathomimetic and metabolic stressor $[1,2]$. As with every other recreational stimulant, this methamphetamine derivative is associated with increased levels of psychiatric distress. The empirical literature of case studies, larger cohort studies, and prospective surveys [3-10], will be reviewed (Table 1). memory/cognition, eating, sleep and sex, show similar doserelated associations with MDMA, suggesting that these psychiatric problems may be part of a wider dimension of neuropsychobiological distress $[2,4]$.

\section{DISCUSSION}

Lieb et al. [7] proposed that: "two basic causal pathways can be assumed: 1. mental disorders lead to substance use... or 2 : mental disorders are consequence of substance use'. These alternative choice models have been suggested by other MDMA researchers, although both models are incomplete as theoretical explanations. The first is restricted to internal factors - the second to external agents. Piaget's theory of Genetic Epistemology, notes that models of knowledge need both

Table 1. Three Explanatory Models for the Association Between Recreational Ecstasy/MDMA, and Psychiatric Distress

\begin{tabular}{|c|c|}
\hline $\begin{array}{l}\text { Premorbid vulnerability. } \\
\qquad[7]\end{array}$ & $\begin{array}{l}\text { Psychiatric problems present prior to MDMA usage. The association reflects a greater use of illicit drugs amongst } \\
\text { disadvantaged groups }\end{array}$ \\
\hline $\begin{array}{l}\text { Drug causation } \\
\qquad[2,4]\end{array}$ & $\begin{array}{l}\text { MDMA is a neuropsychobiological stressor. It has damaging effects on serotonergic and dopaminergic } \\
\text { neurotransmission. It also disrupts the HPA-axis, and can adversely affects neuroendocrine functioning }\end{array}$ \\
\hline $\begin{array}{l}\text { Diathesis-Stress interactions. } \\
\qquad[2,5,8-10]\end{array}$ & $\begin{array}{l}\text { This model combines both above factors. Neuropsychobiological integrity is disrupted by CNS stimulant drugs. } \\
\text { However the form of any emergent problems will reflect a range of prior vulnerability factors, and other } \\
\text { modulatory influences, such as gender, genetics, and environmental co-stimulation. }\end{array}$ \\
\hline
\end{tabular}

\section{RESULTS}

The first individual case studies were published around 1990-1994, soon after MDMA was used for recreational purposes. In a comprehensive review of this case study literature, around one third of individuals had premorbid problems, while most cases did not have prior vulnerability factors [3]. Larger population surveys have found that recreational Ecstasy use is associated with significantly raised levels of depression, anxiety, phobic anxiety, agoraphobia, and paranoid psychosis [4-10]. The occurrence of these problems is associated with lifetime Ecstasy/MDMA usage [4,5]. Furthermore, around 70\% of recreational users report improved psychiatric wellbeing, after quitting ecstasy [6]. Other functional problems in

*Address correspondence to this author at the Department of Psychology, University of Swansea, Swansea SA2 8PP, Wales, UK; Tel: +44(0)1792 295271; Fax: +44(0)1792 295679; E-mail: a.c.parrott@swansea.ac.uk internal and external factors, which interact together in complex and dynamic ways (viz: assimilation and accommodation). The diathesis-stress model provides a far more complete explanation, hence its widespread use in clinical psychiatry. Both causal factors are seen as natural and complementary, rather than contradictory. They are also seen in dimensional terms. Predisposition factors will vary from low to high, with individuals differing in susceptibility to stress [8]. Other modulatory factors may include differences in genetic loading [9], personality, and gender [10]. Drug stressors are also on a continuum, with acute bingeing, lifetime dosage, and combined drug-dancing bioenergetic overstimulation, each associated with more psychiatric distress $[2,4,5]$. In summary, the interactive diathesis-stress model can explain the wide range of potential reactions to recreational stimulant drugs, such as Ecstasy/ MDMA. 


\section{CONCLUSIONS}

Psychiatric distress levels are significantly raised in recreational Ecstasy/MDMA users. Prior disposition factors and drug stressors can both be important, and they are dynamically combined in the diathesis-stress model. Here causation is seen as complex, interactive, and multifactorial.

\section{REFERENCES}

[1] Darvesh AS, Gudelsky GA. Evidence for a role of energy dysregulation in the MDMA-induced depletion of brain 5-HT. Brain Res 2005; 21: 168-75.

[2] Parrott AC. Cortisol and 3, 4-methylenedioxymethamphetamine: neurohormonal aspects of bioenergetic stress in ecstasy users. Neuropsychobiology 2009; 60: 148-58.

[3] Soar K, Turner JJD, Parrott AC. Psychiatric disorders in recreational Ecstasy (MDMA) users: a literature review focusing upon personal predisposition factors and drug histories. Hum Psychopharmacol 2001; 16: 641-46.

[4] Schifano F, Di Furia L, Forza G, Minicuci N, Bricolo R. MDMA ('ecstasy') consumption in the context of polydrug abuse: a report on 150 patients. Drug Alcohol Depend 1998; 52: 85-90.

[5] Parrott AC, Sisk E, Turner J. Psychobiological problems in heavy 'ecstasy' (MDMA) polydrug users. Drug Alcohol Depend 2000; 60: $105-10$.

[6] Verheyden SL, Maidment R, Curran HV. Quitting ecstasy: an investigation of why people stop taking the drug and their subsequent mental health. J Psychopharmacol 2003; 17: 371-8.

[7] Lieb R, Schuetz CG, Pfister H, von Sydow K, Wittchen H-U. Mental disorders in ecstasy users: a prospective-longitudinal investigation. Drug Alcohol Dep 2002; 68: 195-207.

[8] MacInnes N, Handley SL, Harding GFA. Former chronic methylenedioxymethamphetamine (MDMA or ecstasy) users report mild depressive symptoms. J Psychopharmacol 2001; 15: 181-6.

[9] Roiser JP, Cook LJ, Cooper JD, Rubinsztein DC, Sahakian BJ. Association of a functional polymorphism in the serotonin transporter gene with abnormal emotional processing in ecstasy users. Am J Psychiatry 2005; 162: 609-12.

[10] Milani RM, Parrott AC, Turner JJD, Fox HC. Gender differences in self-reported anxiety, depression and somatization, among ecstasy/MDMA polydrug users, alcohol/tobacco uses, and nondrug users. Addict Behav 2004; 29: 965-71.

This is an open access article licensed under the terms of the Creative Commons Attribution Non-Commercial License (http://creativecommons.org/licenses/ by-nc/3.0/) which permits unrestricted, non-commercial use, distribution and reproduction in any medium, provided the work is properly cited. 